\title{
Effect of Herbicides for Leafy Spurge Control on the Western Prairie Fringed Orchid
}

\author{
Ann M. Erickson, ${ }^{1}$ Rodney G. Lym, ${ }^{2}$ and Don Kirby ${ }^{3}$ \\ Authors are ${ }^{1}$ Biological Science Technician (plants), National Park Service, Haleakala National Park, P.O. Box 369, \\ Makawao, Mani, HI 96768; ${ }^{2}$ Professor, Department of Plant Sciences, and ${ }^{3}$ Professor, Animal and \\ Range Sciences Department, North Dakota State University, Fargo, ND 58105.
}

\begin{abstract}
Leafy spurge has invaded the habitat of the western prairie fringed orchid, a federally listed threatened species. Imazapic $([ \pm]-2-$ [4,5-dihydro-4-methyl-4-\{1-methylethyl $\}$-5-oxo- $1 H$-imidazol-2-yl]-5-methyl-3-pyridinecarboxylic acid) and quinclorac (3,7dichloroquinoline-8-carboxylic acid) are relatively new herbicides that control leafy spurge and can be used in the mesic areas where the orchid is found. Research was initiated to evaluate the effects of imazapic and quinclorac on the survival and fecundity of the western prairie fringed orchid. Herbicides were applied at the commonly used and maximum labeled rates in mid-September. This timing is optimum for leafy spurge control with quinclorac and imazapic and the orchid generally has senesced by mid-September, making injury less likely. Quinclorac applied at 840 and $1120 \mathrm{~g} \cdot \mathrm{ha}^{-1}$ did not affect regrowth or fecundity of the western prairie fringed orchid 1 or 2 years after treatment. Orchids treated with quinclorac at 840 or 1120 $\mathrm{g} \cdot \mathrm{ha}^{-1}$ generally were as tall, had racemes as long as, and produced as many flowers and seed capsules as untreated orchids. In contrast, orchids treated with imazapic at 140 or $210 \mathrm{~g} \cdot \mathrm{ha}^{-1}$ tended to regrow as vegetative plants and were shorter, had shorter racemes, and produced fewer flowers and seed capsules than untreated orchids. Orchids treated with imazapic averaged $21 \mathrm{~cm}$ in height and produced an average of 1 flower per plant 10 months after treatment, whereas untreated orchids and orchids treated with quinclorac were approximately $36 \mathrm{~cm}$ in height and produced 5 flowers per plant. Quinclorac could be a valuable tool to control leafy spurge in the habitat of the orchid because orchids treated with quinclorac regrew as vigorously and were as fecund as untreated orchids. However, the current quinclorac label prohibits grazing or haying for 309 days after application.
\end{abstract}

\section{Resumen}

"Leafy spurge" ha invadido el hábitat del "Western prairie fringed orchid," una especie federalmente enlistada como amenazada. El Imazapic([ \pm$]-2$-[4,5-dihidro-4-metil-4-\{1-metiletil\}-5-oxo-1H-imidazol-2-yl]-5-metil-3-ácido piridinecarboxilico) y quinclorac (3,7-dicloroquinolino-8-ácido carboxilico) son herbicidas relativamente nuevos que controlan el "Leafy spurge" y pueden ser usados en las áreas mésicas donde la "Western prairie fringed orchid" es encontrada. Se inicio una investigación para evaluar los efectos del imazapic y quinclorac en la sobrevivencia y fecundidad del "Western prairie fringed orchid." Los herbicidas se aplicaron a mediados de Septiembre en las dosis comúnmente usadas y las máximas especificadas en las etiquetas. Esta época de aplicación es la óptima para el control de "Leafy spurge" con quinclorac e imazapic y la orquídea generalmente ya esta senescente, haciendo que el daño para ella sea menos probable. El quinclorac aplicado en 840 y $1120 \mathrm{~g} \cdot \mathrm{ha}^{-1}$ no afectó el rebrote o la fecundidad del "Western prairie fringed orchid," 1 o 2 años después de la aplicación. Las orquídeas tratadas con quinclorac en dosis de $840 \mathrm{o} 1120 \mathrm{~g} \cdot \mathrm{ha}^{-1}$ generalmente fueron tan altas, tuvieron racimos tan largos, y produjeron tantas flores y cápsulas de semillas como las orquídeas sin tratar. En contraste, las orquídeas tratadas con imazapic en dosis de 140 o 210 $\mathrm{g} \cdot \mathrm{ha}^{-1}$ tendieron a rebrotar como plantas vegetativas, fueron mas cortas, tuvieron racimos más cortos y produjeron menos flores y cápsulas de semillas que las orquídeas sin tratar. Las orquídeas tratadas con imazapic promediaron $21 \mathrm{~cm}$ de altura y produjeron en promedio una flor por planta 10 meses después de aplicado el tratamiento, mientras que las orquídeas sin tratar y las tratadas con quinclorac tuvieron de aproximadamente $36 \mathrm{~cm}$ de altura y produjeron 5 flores por planta. El quinclorac puede ser una herramienta valiosa para controlar el "Leafy spurge" en el hábitat del "Western prairie fringed orchid" porque las orquídeas tratadas con este producto rebrotaron tan vigorosamente y fueron fecundadas como las orquídeas sin tratar. Sin embargo, las especificaciones actuales de uso del quinclorac prohíben el apacentamiento o elaboración de heno por 309 días después de la aplicación.

Key Words: invasive species, threatened species, imazapic, quinclorac

\section{INTRODUCTION}

Research was funded in part by USDA-ARS TEAM leafy spurge.

At the time of the research, the senior author was research assistant, Department of Plant Sciences, North Dakota State University, Fargo, ND 58105.

Correspondence: Dr Rodney G. Lym, Dept of Plant Sciences, North Dakota State University, Fargo, ND 58105. Email: Rod.Lym@ndsu.edu

Manuscript received 12 March 2004; manuscript accepted 19 July 2005.
The western prairie fringed orchid (Platanthera praeclara Sheviak and Bowles) is a native perennial plant of the tallgrass prairie and was once found in large numbers and distributed throughout areas west of the Mississippi River (Sheviak and Bowles 1986). The ideal habitat of the western prairie fringed orchid has subirrigated soils, and the plant is most often found 
Table 1. Annual precipitation at McLeod, ND, approximately $8 \mathrm{~km}$ from the western prairie fringed orchid study location on the Sheyenne National Grassland. ${ }^{1}$

\begin{tabular}{llc}
\hline Year & Actual & Departure $^{2}$ \\
\hline & $--0-10-0$ & +11.8 \\
2000 & 64 & +7.2 \\
2001 & 59.4 & +6.8 \\
2002 & 59.0 & -12.5 \\
2003 & 39.7 & -12.2 \\
\hline
\end{tabular}

${ }^{1}$ Data were obtained from the North Dakota Fire Dispatch Center, Upham, ND.

${ }^{2}$ Departure from 30-year average from 1971 through 2000

in Mollisols, but also in Entisols and a few Inceptisols (U.S. Soil Conservation Service 1975). With the conversion of prairie to cropland and urban development, the orchids have become a rare species. Loss of orchid habitat and the consequential dramatic decrease in the number of populations of the western prairie fringed orchid and isolation of the remaining populations caused the federal government to protect this plant (U.S. Fish and Wildlife Service 1989). Under the 1988 reauthorization of the 1973 Endangered Species Act, the western prairie fringed orchid was listed as a threatened species in an effort to prevent the plant from becoming endangered. Today extant populations of the western prairie fringed orchid are reported in only 41 counties in portions of Iowa, Kansas, Minnesota, Missouri, Nebraska, North Dakota, and in Manitoba, Canada (U.S. Fish and Wildlife Service 1989, 1996).

Various threats to the survival of the western prairie fringed orchid exist and include habitat invasion by leafy spurge (Euphorbia esula L.) (Sieg and Bjugstad 1994; U.S. Fish and Wildlife Service 1996; Wolken et al. 2001). The spread of and competition with alien species such as leafy spurge, is second only to habitat loss as the greatest threat to threatened and endangered species in the United States (Wilcove et al. 1998; Stein et al. 2000). In fact, alien species affect $57 \%$ of imperiled plant species in the United States.

Leafy spurge is very difficult to control with methods other than herbicides, but herbicides cannot be used in areas where the orchid is located because the orchid is a federally listed threatened species. Biological control of leafy spurge in the habitat of the threatened orchid species would seem to be the least harmful approach. However, control of leafy spurge with the use of Aphthona spp. flea beetles (Carlson and Mundal 1990) has not yet been successful in the habitat of the western prairie fringed orchid (Lym 1998; Mundal et al. 2000). Aphthona spp. usually do not survive well in habitats that are moist, shady, or contain sandy soil, which are characteristics of the habitat of the western prairie fringed orchid.

An experiment to evaluate herbicides for leafy spurge control in North Dakota in the early 1990s had to be discontinued 2 years after initiation because the western prairie fringed orchid appeared in areas treated with fall-applied herbicides (Kirby et al. 2003). Subsequent research found imazapic and quinclorac provided good leafy spurge control with little or no apparent injury to the orchid but the study had to be prematurely terminated due to flooding of the research site (Sterling et al. 2000a, 2000b; Kirby et al. 2003). Therefore, this study was specifically initiated to evaluate the effects of imazapic and quinclorac on the regrowth and fecundity of the western prairie fringed orchid with a secondary objective of demonstrating the use of herbicides to control invasive species while minimizing the impact to threatened species.

\section{MATERIALS AND METHODS}

A permit to apply the herbicides imazapic and quinclorac to western prairie fringed orchids on the Sheyenne National Grassland (SNG) was obtained from the U.S. Fish and Wildlife Service. One of the largest remaining populations of the orchid is found on the SNG, which is located in southeastern North Dakota (Sieg and Wolken 1999). A portion of the SNG containing 85 orchids in Section 25 of Venlo Township, Ransom County, North Dakota, was chosen for this study in July 2000. The plants were located primarily in low-lying swales mainly consisting of prairie cordgrass (Spartina pectinata Bosc. ex Link) and on the sides of upland areas near the swales. Other associated plants included bluegrass (Poa spp.), leafy spurge, and willow (Salix spp.). The soil was classified as a Hecla-Hamar-Arveson association, which includes sandy, mixed, frigid Oxyaquic Hapludolls; sandy, mixed, frigid Typic Endoaquolls; and coarse-loamy, mixed, superactive, frigid Typic Calciaquolls; respectively (U.S. Soil Conservation Service 1975). The soil was 75:20:5 sand:silt:clay, with a $\mathrm{pH}$ of 7.1, and $4.3 \%$ organic matter. Annual precipitation was above average from 1999 through 2001, but below average in 2002 and 2003 (Table 1).

Each orchid was marked three ways: with a colored flag that corresponded to the treatment, a numbered livestock ear tag, and a metal washer. The ear tags and washers were secured to the ground with nails so that an individual orchid could be relocated with a metal detector if needed. The location of each orchid was mapped, and distances from orchids to a post were recorded.

Herbicides were applied to $1 \mathrm{~m}^{2}$ areas, each containing a single orchid, using a $\mathrm{CO}_{2}$-pressurized backpack sprayer at $240 \mathrm{kPa}$. The boom contained two 8001 flat-fan nozzles (TeeJet $^{\circledR}$ Agricultural Spray Products, Spraying Systems Co., P.O. Box 7900, Wheaton, IL 60189) delivering $80 \mathrm{~L} \cdot \mathrm{ha}^{-1}$. Imazapic was applied at 140 or $210 \mathrm{~g} \cdot \mathrm{ha}^{-1}$ and quinclorac at 840 or $1120 \mathrm{~g} \cdot \mathrm{ha}^{-1}$ which were the common- and maximumlabeled use rates for leafy spurge control. Orchids designated as control plants were untreated. Herbicides were applied on 21 September 2000, which was timed to provide optimal leafy spurge control following senescence of the orchid (Kirby et al. 2003). An additional 17 replicates of flowering orchids were marked in July 2001, and the experiment was repeated on September 20, 2001.

Plots were revisited during the summers of 2001 through 2003 to determine if orchids regrew and the life state (vegetative or flowering) of orchids. Of the regrowing orchids, plant vigor was estimated by determining the heights, raceme lengths, numbers of leaves, numbers of flower heads, and numbers and morphological states of seed capsules on each orchid. Plant height was measured from the base of the plant (soil level) to the end of the longest leaf of a vegetative plant and to the top of the raceme of a flowering plant. Swollen seed capsules resulted from pollinated flowers and contained a maximum number of seeds, 
Table 2. The effect of imazapic and quinclorac on western prairie fringed orchid regrowth and number of leaves 10 and 22 months after treatment in 2000 or 2001 (averaged across years).

\begin{tabular}{|c|c|c|c|c|c|}
\hline \multirow[b]{2}{*}{ Treatment } & \multirow[b]{2}{*}{ Rate } & \multicolumn{2}{|c|}{ Orchids within $1 \mathrm{~m}^{2}$ plots ${ }^{1}$} & \multicolumn{2}{|c|}{ Leaves per plant } \\
\hline & & $10 \mathrm{mo}$ & $22 \mathrm{mo}$ & $10 \mathrm{mo}$ & $22 \mathrm{mo}$ \\
\hline & $---g \cdot h a^{-1}--$ & - & ----No. & $\cdots$ & ------- \\
\hline Imazapic + MSO $^{2}$ & 140 & 1.2 & 0.8 & 5 & 5 \\
\hline Imazapic + MSO & 210 & 1.3 & 0.7 & 4 & 4 \\
\hline Quinclorac + MSO & 840 & 1.1 & 0.9 & 5 & 4 \\
\hline Quinclorac + MSO & 1120 & 1 & 0.7 & 5 & 4 \\
\hline Control & Untreated & 1 & 0.9 & 5 & 4 \\
\hline LSD (0.05) & & NS & NS & NS & NS \\
\hline SE & & 0.19 & 0.15 & 0.5 & 0.8 \\
\hline
\end{tabular}

${ }^{1}$ Occasionally more than one orchid regrew per plot.

${ }^{2} \mathrm{MSO}$, methylated seed oil at $2.3 \mathrm{~L} \cdot \mathrm{ha}^{-1}$.

partially swollen capsules contained some seed, and twisted seed capsules resulted from flowers that had not been pollinated.

One seed capsule was collected from each plant in five random replicates per experiment in September 2001 and 2002. The federal permit obtained for this research allowed a total of 25 seed capsules to be collected per year (five plants in five replicates). In September 2001, the third seed capsule from the top of the raceme was collected. Because most of those seed capsules were twisted and contained no seed, the most swollen seed capsule was collected from each plant in the selected replicates in September 2002. Fecundity was estimated by determining the numbers of seeds within collected seed capsules and evaluation of seed viability. Seeds were considered viable when the embryos, as seen under a dissection microscope, were distinct, round, and hyaline (Zettler et al. 2001).

The orchid herbicide efficacy experiment was arranged as a noncontiguous randomized complete block-design with five treatments and 17 blocks and was repeated. A block consisted of five closely spaced orchids. All measures were compared to an untreated check using analyses of variance (ANOVA) for separate runs and using combined analyses of variance across runs of the experiments when data were homogeneous. In the combined analyses, the effect of years was considered random, and the effect of treatments was considered fixed. Individual treatment means were separated using Fischer's Protected LSDs.

\section{RESULTS AND DISCUSSION}

The number of western prairie fringed orchids that regrew was unaffected 1 or 2 years after broadcast application of imazapic or quinclorac (Table 2). Data were combined over years (34 replications total), and occasionally more than one orchid regrew per plot. These results agree with previous research which found the reoccurrence and density of the western prairie fringed orchid was unaffected by imazapic and quinclorac 1 year after treatment (Kirby et al. 2003). Neither herbicide affected the number of leaves per plant compared to the control (Table 2).

Data on life state could not be combined over years because a larger percentage of plants were absent in 2002 than in 2001 (Table 3). The decrease in orchid population likely resulted
Table 3. The effect of imazapic and quinclorac on western prairie fringed orchid life state 10 or 22 months after treatment in 2000 or 2001.

\begin{tabular}{|c|c|c|c|c|c|c|c|}
\hline \multirow[b]{2}{*}{ Treatment } & \multirow[b]{2}{*}{ Rate } & \multicolumn{2}{|c|}{ Flowering } & \multicolumn{2}{|c|}{ Vegetative } & \multicolumn{2}{|c|}{ Absent } \\
\hline & & 2000 & 2001 & 2000 & 2001 & 2000 & 2001 \\
\hline & $---g \cdot h^{-1}---$ & ---- & 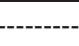 & ---- & 10--- & 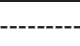 & ------ \\
\hline \multicolumn{8}{|l|}{10 mo after treatment } \\
\hline Imazapic + MSO ${ }^{1}$ & 140 & 53 & 71 & 41 & 17 & 6 & 12 \\
\hline Imazapic + MSO & 210 & 41 & 71 & 53 & 11 & 6 & 18 \\
\hline Quinclorac + MSO & 840 & 76 & 71 & 12 & 5 & 12 & 24 \\
\hline Quinclorac + MSO & 1120 & 76 & 47 & 18 & 6 & 6 & 47 \\
\hline Control & Untreated & 69 & 71 & 12 & 0 & 19 & 29 \\
\hline LSD (0.05) & & 31 & NS & 29 & NS & NS & 31 \\
\hline SE & & 15 & 17 & 14 & 10 & 10 & 15 \\
\hline \multicolumn{8}{|l|}{22 mo after treatment } \\
\hline Imazapic $+\mathrm{MSO}^{1}$ & 140 & 71 & 12 & 6 & 29 & 24 & 59 \\
\hline Imazapic + MSO & 210 & 44 & 18 & 6 & 41 & 50 & 41 \\
\hline Quinclorac + MSO & 840 & 59 & 6 & 18 & 41 & 24 & 53 \\
\hline Quinclorac + MSO & 1120 & 71 & 12 & 18 & 18 & 12 & 70 \\
\hline Control & Untreated & 50 & 6 & 19 & 29 & 31 & 65 \\
\hline LSD (0.05) & & NS & NS & NS & NS & NS & NS \\
\hline SE & & 18 & 10 & 12 & 17 & 16 & 17 \\
\hline
\end{tabular}

${ }^{1} \mathrm{MSO}$, methylated seed oil at $2.3 \mathrm{~L} \cdot \mathrm{ha}^{-1}$.

from the drier conditions in 2002 than in 2001 (Table 1). Sieg and King (1995) positively correlated orchid density with soil moisture in the current and previous year and positively correlated density of flowering orchids with soil moisture in the current year.

Quinclorac did not affect the life state of regrowing orchids 10 or 22 months after treatment (MAT) (Table 3), but imazapic tended to cause the orchids that regrew to remain vegetative rather than flower 10 MAT in 2000 . Only $12 \%$ of untreated orchids in 2000 compared to $41 \%$ of the orchids treated with $140 \mathrm{~g} \cdot \mathrm{ha}^{-1}$ of imazapic and $53 \%$ of the orchids treated with $210 \mathrm{~g} \cdot \mathrm{ha}^{-1}$ of imazapic regrew as vegetative plants 10 MAT. Those plants treated with $140 \mathrm{~g} \cdot \mathrm{ha}^{-1}$ of imazapic that were vegetative 10 MAT tended to flower 22 MAT, whereas those plants treated with $210 \mathrm{~g} \cdot \mathrm{ha}^{-1}$ of imazapic that were vegetative 10 MAT generally were absent 22 MAT. Of the plants treated with $210 \mathrm{~g} \cdot \mathrm{ha}^{-1}$ of imazapic in $2000,50 \%$ failed to regrow 22 MAT, compared to $31 \%$ of the untreated orchids. The failure to regrow is critical because when this orchid species becomes absent, it rarely regrows (Sieg and King 1995).

Orchids treated with imazapic in 2001 also tended to return as vegetative plants more often than the untreated control 10 MAT, but many more plants were absent 22 MAT regardless of treatment (Table 3 ). This decline in orchid number was likely due to drier growing conditions in 2002 compared to the previous 3 years of the study (Table 1). The herbicide treatments did not seem to exacerbate the decline in orchid numbers during the dry weather, which is important for future leafy spurge control programs conducted in orchid habitat. Although imazapic injured the orchid, the combination of herbicide with drier growing conditions was not additive.

Quinclorac did not affect western prairie fringed orchid height, raceme length, or the number of flowers produced per plant 10 or 22 MAT (Table 4). However, orchids treated with 
Table 4. The effect of imazapic and quinclorac on western prairie fringed orchid regrowth 10 months and 22 months after treatment in 2000 or 2001 (averaged across years).

\begin{tabular}{|c|c|c|c|c|c|c|c|}
\hline \multirow[b]{2}{*}{ Treatment } & \multirow[b]{2}{*}{ Rate } & \multicolumn{2}{|c|}{ Plant height } & \multicolumn{2}{|c|}{ Raceme length } & \multicolumn{2}{|c|}{ Flowers } \\
\hline & & $10 \mathrm{mo}$ & $22 \mathrm{mo}$ & $10 \mathrm{mo}$ & $22 \mathrm{mo}$ & $10 \mathrm{mo}$ & $22 \mathrm{mo}$ \\
\hline & $---g \cdot h a^{-1}--$ & - -----. & $\begin{array}{ll}-------c \\
\end{array}$ & cm---- & - & $---\mathrm{No} . /$ & blant--- \\
\hline Imazapic $+\mathrm{MSO}^{1}$ & 140 & 21.3 & 17.5 & 0.8 & 1.4 & 1.7 & 3.5 \\
\hline Imazapic + MSO & 210 & 19.7 & 10.1 & 1.2 & 0.5 & 1.1 & 1.0 \\
\hline Quinclorac + MSO & 840 & 33.1 & 15.6 & 3.8 & 1.5 & 4.1 & 2.3 \\
\hline Quinclorac + MSO & 1120 & 35.5 & 18.5 & 4.7 & 1.5 & 5.1 & 3.4 \\
\hline Control & Untreated & 35.8 & 15.6 & 4.6 & 1.2 & 5.1 & 3.3 \\
\hline $\operatorname{LSD}(0.10)$ & & 9 & NS & 1.1 & 0.8 & 1.3 & 2 \\
\hline SE & & 8.4 & 4.1 & 2.1 & 0.56 & 0.13 & 1.6 \\
\hline
\end{tabular}

${ }^{1} \mathrm{MSO}$, methylated seed oil at $2.3 \mathrm{~L} \cdot \mathrm{ha}^{-1}$

imazapic tended to be shorter with shorter raceme lengths, and produced fewer flowers 10 MAT than untreated orchids. Orchids treated with imazapic averaged $21 \mathrm{~cm}$ in height and produced an average of 1 flower per plant 10 MAT, whereas untreated orchids were approximately $36 \mathrm{~cm}$ in height and produced 5 flowers. All orchid plants were shorter and produced fewer flowers 22 MAT compared to 10 MAT, which was probably due to drier conditions in the later stages of the study. However, orchids treated with imazapic at $210 \mathrm{~g} \cdot \mathrm{ha}^{-1}$ only averaged one flower per plant 22 MAT compared to over three flowers on untreated plants.

The flowers of plants treated with imazapic were deformed as well. The lips of deformed flowers were neither lobed nor fringed both 10 and 22 MAT (Fig. 1). The effect of deformation on pollination is unknown.

Orchids treated with imazapic produced fewer partially swollen seed capsules 12 MAT than untreated orchids (Table $5)$. An average of 0.3 compared to an average of 2.1 partially swollen seed capsules were produced by orchids treated with imazapic compared to untreated orchids, respectively. Swollen and partially swollen seed capsules result from pollinated flowers and can contain viable seeds, whereas twisted seed capsules are formed when flowers have not been pollinated and, therefore, do not contain viable seeds (Fig. 2) (L.W. Zettler, personal communication, 2002). Of note, orchids treated with imazapic at $140 \mathrm{~g} \cdot \mathrm{ha}^{-1}$ generally failed to produce mature flowers $10 \mathrm{MAT}$, and with imazapic at $210 \mathrm{~g} \cdot \mathrm{ha}^{-1}$ few flowers were produced 10 or 22 MAT (Table 4). Thus, these plants failed to produce seed capsules that might contain viable seeds.

Quinclorac did not affect seed production of the western prairie fringed orchid; however, because imazapic reduced
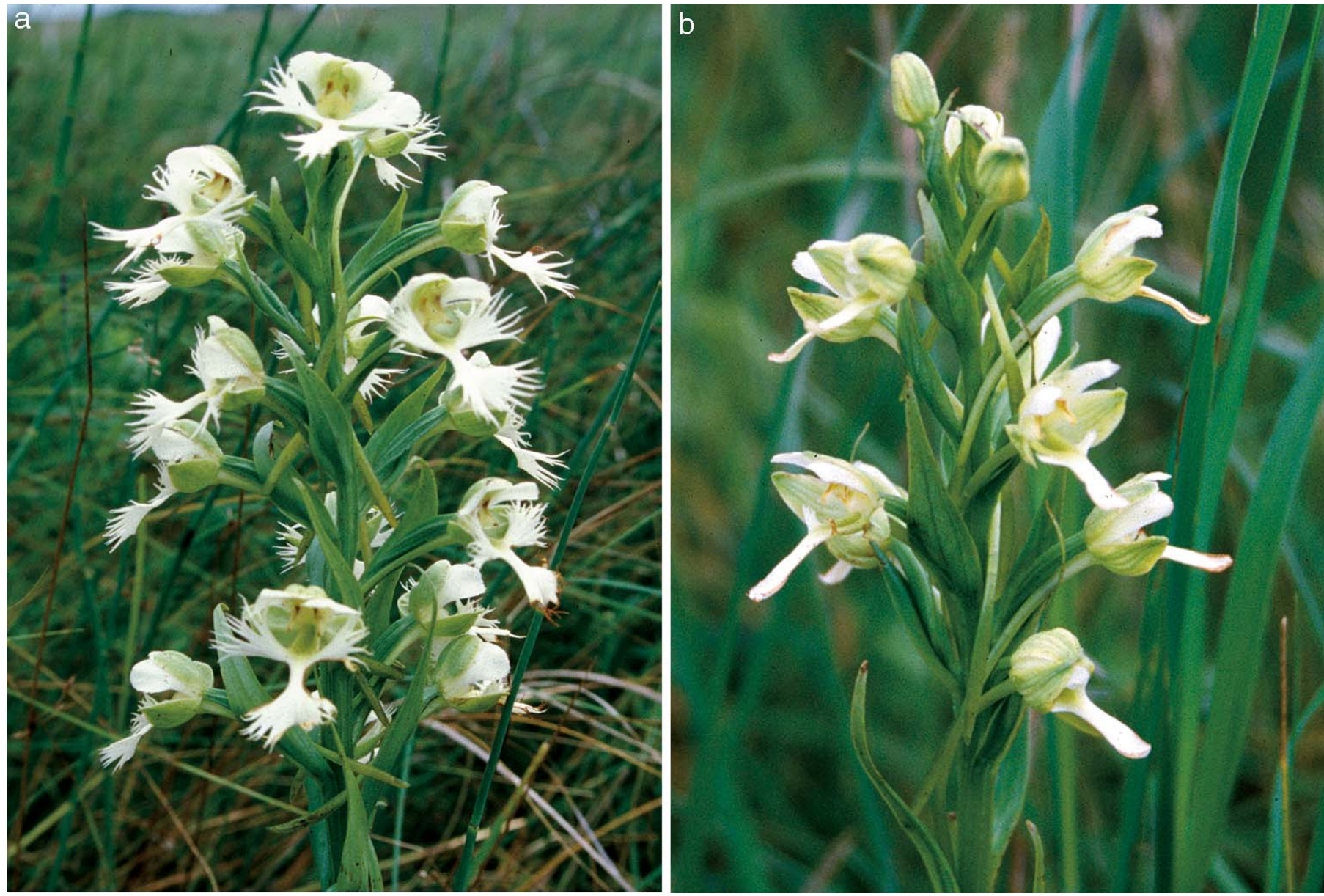

Figure 1. Inflorescence of the western prairie fringed orchid. Each flower is 5 to $22 \mathrm{~cm}$ long, 4 to $10 \mathrm{~cm}$ wide, and blooms as long as 10 days. The lower petal (lip) of an untreated flower is deeply three-lobed and fringed (a) compared to injured flowers (b) which are smaller and generally not lobed or fringed following treatment with imazapic. 
Table 5. The effect of imazapic and quinclorac on western prairie fringed orchid fecundity 12 months after treatment.

\begin{tabular}{|c|c|c|c|c|c|}
\hline \multirow[b]{2}{*}{ Treatment } & \multirow[b]{2}{*}{ Rate } & \multicolumn{4}{|c|}{ Capsules } \\
\hline & & Total & Twisted $^{1}$ & $\begin{array}{l}\text { Partially } \\
\text { swollen }\end{array}$ & Swollen \\
\hline & $---g \cdot h a^{-1}---$ & \multicolumn{4}{|c|}{-------------- No./raceme --------------- } \\
\hline Imazapic + MSO $^{2}$ & 140 & 1.1 & 1.1 & 0.1 & 0 \\
\hline Imazapic + MSO & 210 & 2.3 & 0.9 & 0.4 & 1 \\
\hline Quinclorac + MSO & 840 & 4.4 & 1.5 & 2.4 & 0.5 \\
\hline Quinclorac + MSO & 1120 & 5.3 & 1.7 & 2.4 & 1.2 \\
\hline Control & Untreated & 4.9 & 1.6 & 2.1 & 1.2 \\
\hline LSD (0.05) & & 3 & NS & 1.9 & NS \\
\hline SE & & 1.5 & 1 & 0.93 & 0.61 \\
\hline
\end{tabular}

${ }^{1}$ Twisted seed capsules do not contain viable seeds.

${ }^{2} \mathrm{MSO}$, methylated seed oil at $2.3 \mathrm{~L} \cdot \mathrm{ha}^{-1}$.

flower production of the orchid, imazapic also reduced seed production (Table 6). Most seed capsules produced by orchids treated with imazapic were twisted (Table 5) and thus did not produce seed. The numbers and viability of seeds produced by the western prairie fringed orchid are important because adult survival and seedling recruitment are the sole means of long-term maintenance for the orchid species and because the pollinators of the orchid such as sphinx moths (Lepidoptera: Sphingidae) are not specific to the orchid (Bowles 1983). Sphinx moths travel large distances to find nectar sources and will likely only visit populations large enough to provide sufficient amounts of nectar. Twisted seed capsules result when orchid flowers have not been pollinated. Twisted seed capsules contained no seeds, only ovules, and thus did not contribute to the maintenance of the species.

Generally, only untreated orchids and orchids treated with quinclorac produced swollen seed capsules (Table 5). Quinclorac did not appear to impact the numbers or viability of the seeds contained in swollen seed capsules (Table 6). Swollen seed capsules of both untreated orchids and orchids treated with quinclorac contained up to approximately 15000 seeds that ranged in viability from 7 to $15 \%$. These viability results differ from previous studies on this species (C. Sieg, personal communication, 2002). In those studies, a seed was considered viable as long as it contained an embryo, whereas in this study, a seed was considered viable only when the embryo was round and hyaline. Thus, approximately half as many seeds were considered viable in this study compared to previous studies. However, in the previous studies, ratios of viable seeds between swollen and partially swollen seed capsules were similar to those ratios in this study.

Quinclorac might be a valuable tool to control leafy spurge in the habitat of the orchid; however, imazapic could have a negative effect on both plant population and flower production. Control of leafy spurge with quinclorac in areas where leafy spurge is invading the habitat of the western prairie fringed orchid might be beneficial to the orchid, likely because control of leafy spurge reduces competition for resources. Bowles (1983) and Sieg and King (1995) suggested that the western prairie fringed orchid survives best in areas with little competition from invasive plants.
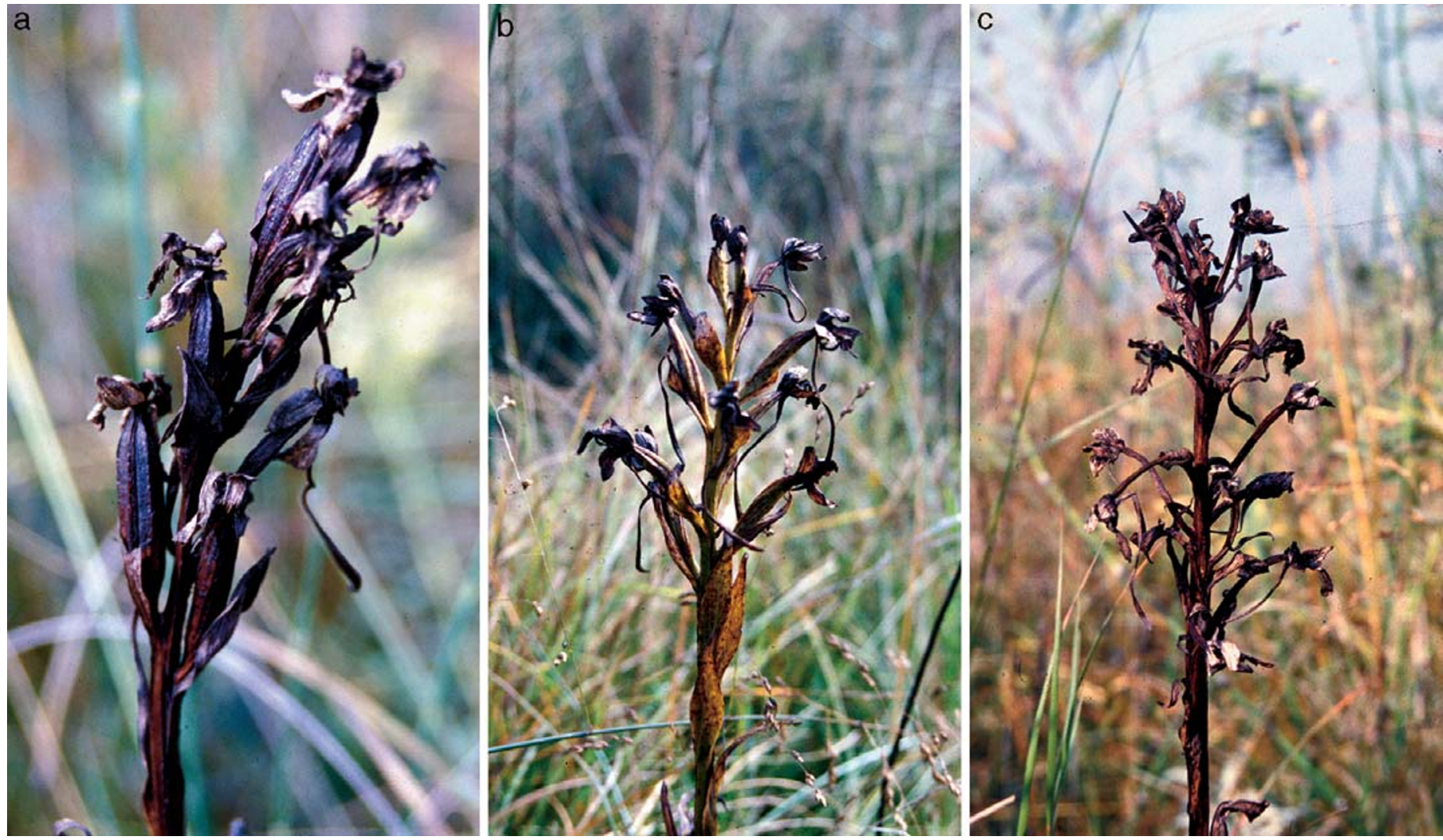

Figure 2. Swollen (a), partially swollen (b), and twisted (c) western prairie fringed orchid seed capsules. 
Table 6. Observations ${ }^{1}$ of seed production and viability of the western prairie fringed orchid treated with imazapic and quinclorac, from seed capsules collected 12 and 24 months after treatment.

\begin{tabular}{|c|c|c|c|c|}
\hline Treatment & Rate & Capsule state & Seeds & Viability \\
\hline & $---g \cdot h a^{-1}---$ & & No./capsule ${ }^{2}$ & --- \%--- \\
\hline \multicolumn{5}{|l|}{12 mo after treatment } \\
\hline Imazapic $+\mathrm{MSO}^{3}$ & 140 & partially swollen & 3350 & 3 \\
\hline Imazapic + MSO & 210 & twisted & 0 & 0 \\
\hline Quinclorac + MSO & 840 & swollen & $\sim 15000$ & 15 \\
\hline Quinclorac + MSO & 1120 & swollen & $\sim 15000$ & 7 \\
\hline Control & Untreated & partially swollen & 4120 & 0 \\
\hline \multicolumn{5}{|l|}{24 mo after treatment } \\
\hline Imazapic + MSO $^{3}$ & 140 & partially swollen & 4130 & 0 \\
\hline Imazapic + MSO & 210 & twisted & 0 & 0 \\
\hline Quinclorac + MSO & 840 & swollen & $\sim 10000$ & 15 \\
\hline Quinclorac + MSO & 1120 & partially swollen & $\sim 7000$ & 5 \\
\hline Control & Untreated & swollen & $\sim 13000$ & 13 \\
\hline
\end{tabular}

${ }^{1}$ Statistical analyses were not conducted because of an insufficient number of observations.

${ }^{2}$ Up to 5000 seeds were counted per seed capsule, and if a seed capsule contained more than 5000 seeds, the remaining number of seeds per seed capsule was visually estimated. Data are averaged over all viable seed capsules collected per treatment from five replicates as limited by research permit.

${ }^{3} \mathrm{MSO}$, methylated seed oil at $2.3 \mathrm{~L} \cdot \mathrm{ha}^{-1}$.

Currently, quinclorac is labeled at a maximum application rate of $560 \mathrm{~g} \cdot \mathrm{ha}^{-1}$, which is less than optimum for leafy spurge control (Lym 1998). Also, grazing and haying are prohibited for 309 days after application. Quinclorac would be the herbicide of choice to control leafy spurge without harm to the western prairie fringed orchid, but the use of this herbicide will be limited until a full federal label is obtained. Imazapic is the only other herbicide currently available for leafy spurge control that can be used in the mesic habitat of the orchid (Lym 1998; Kirby et al. 2003). Imazapic applied at lower rates than used in this study (70 to $105 \mathrm{~g} \cdot \mathrm{ha}^{-1}$ ) can provide leafy spurge control for at least 1 year (Markle and Lym 2001) and potentially would be less injurious to the orchid than higher rates. If nothing is done, the population of this threatened species likely will continue to decline as leafy spurge spreads further into orchid habitat.

This research demonstrates the potential to use herbicides in the habitats of a threatened or endangered species to control invasive weeds. Although the use of nonchemical means such as biological control agents or cultural methods are often considered, they might not always be available or the most effective method to control the weed. The careful use of selective herbicides is a useful option that should be a considered part of any invasive weed control program, including those that deal with threatened and endangered plants. The resultant weed control obtained by herbicides might ultimately save a threatened or endangered species from one of the plants greatest dangers.

\section{ACKNOWLEDGMENT}

The authors wish to thank Katheryn Christianson for technical assistance with field work and data analysis.

\section{LITERATURE CITED}

Bowles, M. L. 1983. The tallgrass prairie orchids: Platanthera leucophaea (Nutt.) Lindl. and Cypripedium candidum Mulh. ex Willd.: some aspects of their status, biology and ecology and implications toward management. Natural Areas Journal 3(4):14-37.

Carlson, R. B., and D. Mundal. 1990. Introduction of insects for the biological control of leafy spurge in North Dakota. North Dakota Farm Research 47:7-8.

Kirby, D. R., R. G. Lym, J. J. Sterling, and C. H. Sieg. 2003. Observation: leafy spurge control in western prairie fringed orchid habitat. Journal of Range Management 56:466-473.

LYM, R. G. 1998. The biology and integrated management of leafy spurge (Euphorbia esula) on North Dakota rangeland. Weed Technology 12: 367-373.

MarkLe, D. M., And R. G. Lym. 2001. Leafy spurge (Euphorbia esula) control and herbage production with imazapic. Weed Technology 15:474-480.

Mundal, D. A., D. L. Olson, and R. B. Carlson. 2000. The effect of Aphthona spp. flea beetle (Coleoptera: Chrysomelidae) larval feeding on leafy spurge, Euphorbia esula L., root systems and stem density in North Dakota: 19861996. USDA-ARS TEAM Leafy Spurge Report, Sidney, MT 59270. 2 p.

Sheviak, C. J., AND M. L. Bowles. 1986. The prairie fringed orchids: a pollinatorisolated species pair. Rhodora 88:267-290.

Sieg, C. H., And A. J. Buugstad. 1994. Five years of following the western prairie fringed orchid (Platanthera praeclara) on the Sheyenne National Grassland, North Dakota. In: R. G. Wickett, P. D. Lewis, A. Woodliffe, and P. Pratt [EDS.]. Proceedings of the Thirteenth North American Prairie Conference. Windsor, ON, Canada: Department of Parks and Recreation. p 141-146.

Sieg, C. H., and R. M. King. 1995. Influence of environmental factors and preliminary demographic analyses of a threatened orchid, Platanthera praeclara. American Midland Naturalist 134:307-323.

Sieg, C. H., AND P. M. Wolken. 1999. Dynamics of a threatened orchid in flooded wetlands. In: J. T. Springer [ED.]. Proceedings of the Sixteenth North American Prairie Conference. Kearney, NE: University of Nebraska. p 193-201.

Stein, B. A., L. S. Kutner, And J. S. Adams (eds.). 2000. Precious heritage: the status of biodiversity in the United States. New York, NY: Oxford University Press. $399 \mathrm{p}$.

Sterling, J. J., D. R. KirBy, R. G. Lym, and C. H. Sieg. 2000a. Response of the western prairie fringed orchid to herbicides for leafy spurge. Proceedings of the Western Society of Weed Science. 53:98.

Sterling, J. J., R. G. Lym, And D. R. KirBy. 2000b. Response of the prairie fringed orchid to herbicides for leafy spurge control. Research Progress Report of the Western Society of Weed Science. p 207-209.

U.S. FiSH And WiLdife SeRvice. 1989. Endangered and threatened wildlife and plants: determination of threatened status for Platanthera leucophaea (eastern prairie fringed orchid) and Platanthera praeclara (western prairie fringed orchid). Federal Register 54:39857-39862.

U.S. FISH ANd WILDLIFE SERVICE. 1996. Platanthera praeclara (western prairie fringed orchid) recovery plan. Ft. Snelling, MN: U.S. Fish and Wildlife Service. $101 \mathrm{p}$.

U.S. Soll Conservation Service. 1975. Soil survey of Richland County, and Sheyenne National Grassland Area of Ransom County, North Dakota. Washington, DC: U.S. Government Printing Office. 141 p.

Wilcove, D. S., D. Rothstein, J. Dubow, A. Philips, and E. Losos. 1998. Quantifying threats to imperiled species in the United States. BioScience 48: 607-615.

Wolken, P. M., C. H. Sieg, and S. E. Williams. 2001. Quantifying suitable habitat of the threatened western prairie fringed orchid. Journal of Range Management 54:611-616.

Zettler, L. W., S. L. Stewart, M. L. Bowles, and K. A. Jacobs. 2001. Mycorrhizal fungi and cold-assisted symbiotic germination of the federally threatened eastern prairie fringed orchid, Platanthera leucophaea (Nuttall) Lindley. American Midland Naturalist 145:168-175. 